\title{
ФОРМЕ СТАНДАРДНОГ СРПСКОГ ЈЕЗИКА У СИРИНИЋКОМ ГОВОРУ
}

\begin{abstract}
Прилог се заснива на анализи транскрипта разговора у којем учествују четири особе, говорници сиринићког говора, који припада призренско-тимочкој дијалекатској области. Иако се у свакодневној комуникацији служе локалним варијететом, саговорници су у оквиру образовног система усвајали стандардни српски језик, којем су свакодневно изложени и преко медија које прате, па се у њиховом изразу могу приметити и стандарднојезичке форме. Оне чине предмет овог истраживања. У раду се истражују њихова употреба и заступљеност у деклинацији именица и личних заменица са циљем да се утврди да ли је реч о контекстуално условљеним одступањима или о потенцијалним променама у систему овог говора. Анализи је приступљено издвајањем граматичких облика који припадају стандардном српском језику и проналаском њима еквивалентих дијалекатских. Квантификацијом варијаната потврђено је да је вернакулар заступљенији, а применом квалитативне анализе примера утврђено је да је присуство стандарднојезичких форми у вернакулару контекстуално условљено. Говорници стандарднојезичке елементе користе у три случаја: у посебно стилизованим исказима и у онима који се односе на одређену тему; у оквиру идиоматских израза, који се перципирају као целина са јединственим значењем због којег говорници мање или уопште не примећују да се у оквиру њих служе формама нетипичним за свој уобичајен говор; и као средство за емфатичко истицање, у комбинацији са логичким акцентом у реченици.
\end{abstract}

Кључне речи: периферни говор, вернакулар, стандард, деклинација, именице, личне заменице, варијација

\section{1. Увод}

Једно од кључних питања у дијалектолошким истраживањима јесте избор информатора, јер су традиционална дијалектолошка истраживања углавном усмерена на документовање „основног” дијалекта (или локалног варијетета / говора), без примеса и утицаја других језика и језичких варијетета. Имајући у виду да се претпоставља да ове дијалектолошке критеријуме

\footnotetext{
${ }^{1}$ andjela.redzic@gmail.com

2 Рад настао као резултат рада у Балканолошком институту САНУ који финансира Министарство просвете, науке и технолошког развоја РС а на основу Уговора о реализацији и финансирању научноистраживачког рада НИО у 2021. години број: 451-03-9/2021-14/200170 од 05.02.2021.
} 
задовољавају само најстарији говорници дијалекта (или говора), који током свог живота нису напуштали место рођења и на чији говор нису утицали формално образовање и медији (Белић, 1905: XCVIII-XCIX), говор младих се најчешће изоставља из дијалектолошке анализе. Претпоставља се да је говор млађе генерације (младих) 'контаминиран' елементима из других језичких варијетета (у које се убраја и стандардни језик) који у њихов говор улазе путем школе, медија, личних контаката са говорницима различитих варијетета српског језика. Говор млађих се пак узима у истраживањима урбане дијалектологије, ${ }^{3}$ када се испитује говор града, пошто она „морају обухватити говорну продукцију испитиване средине у њеном тоталитету" (Бугарски, 2009: 19). ${ }^{4}$ Овде се као главно питање издвајају варијације „у зависности од саговорника̂, говорне ситуације и друштвеног контекста" (Бугарски, 2009: 19). Када се у обзир узму данашња урбанизација села и савремене миграције ${ }^{5}$ могло би се поставити питање да ли би постулати урбане дијалектологије били од значаја уколико би се применили и у истраживању говора села. Ипак, за истраживање говора мањих места из угла урбане дијалектологије било би пре свега потребно имати одговоре на теоријска питања ${ }^{6}$, а затим и саме поставке додатно прилагодити. Стога се у овом раду њихов говор испитује полазећи од тога да је одабрана категорија (деклинација) једнака дијалекатском опису, али и да би се пронађене варијанте морале истражити у складу са неким додатним параметрима попут утицаја саговорника, говорне ситуације, теме и сл. Оправдање за овакав мешовит приступ проналазимо у томе што се и у традиционалном приступу дијалектолошким истраживањима све више посвећује пажња и говору младих (нпр. Трајковић, 2015: 342-368), иако се он изузима из основног дијалекатског описа.

Термин вернакулар, који В. Лабов дефинише као први језик који говорник научи, контролише перфектно и користи у комуникацији са блиским

\footnotetext{
${ }^{3}$ Један од најзначајнијих и пионирских радова у испитивању говора града свакако јесте The Social Stratification of English in New York City B. Лабова (Labov, 1966), а оваква истраживања такође дају значајне резултате и у српској лингвистици нпр. Говор Новог Сада (Бошњаковић и др., 2009), а посебно у вези са диглосијом у говору Ниша (Тома, 1998, Трајковић, 2018 и Трајковић, 2017).

${ }^{4}$ Јер „постаје мање важно ко потиче одакле у географском погледу, а све је важније ко је ко у социоекономском смислу, на скали друштвеног престижа” (Бугарски, 2009: 16).

5 Под савременим миграцијама подразумевамо данашње кретање становништва из села у град, некада и на дневном нивоу (о дневним миграцијама на релацији село-града пише и Милорадовић, 2016: 86), што је понекад случај и са онима из Сиринића који путују у Косовску Митровицу због посла или студија.

${ }^{6}$ Питања попут да ли је тип насеља довољно значајан да диктира теоријски оквир и методологију (и да ли се једнако могу проучавати говори села из различитих дијалекатских зона); с друге стране, да ли узраст и образовање заједно са модерним технологијама, односно медијима, могу имати толико значајан утицај на језик, односно промену у њему.
} 
пријатељима и породицом (Labov, 2006: 86) могао би се користити и у дијалектолошком контексту као језички варијетет, различит од стандардног језика, који се усваја и користи у породици, од говорника који су у дијалектолошком смислу „идеални информатори”. Иако свој говор мењају, млађи говорници познају одлике свог локалног говора које су постојане у говору старијих генерација. Вернакулар млађе генерације чине језички обрасци усвојени најраније у породици заједно са обрасцима из других варијетета прихваћеним у току школовања, језичког контакта и путем медија. Код ових говорника дијалекатске црте могу коегзистирати са касније прихваћеним цртама из стандарда и они их могу користити у различитим приликама и са различитом интенцијом. Језичке црте млађих говорника могле би се истражити у ситуацијама за које је наведено да се у њима вернакулар јавља, како би се дошло до прецизнијих сазнања о односу употребе локалног говора каквим се служе старији говорници и новина насталих под различитим околностима. Предуслов за такво истраживање био би материјал добијен у породичном, блиском окружењу и детаљан опис говора о којем је реч. У овом раду се на таквој грађи и са ослонцем на дијалектолошки опис изворног говора истражује вернакулар млађих житеља Сиринићке жупе. Предмет анализе су форме стандардног српског језика у деклинацији именица и личних заменица у њиховом вернакулару. У овом се раду полази од тога да је деклинација која се испитује идентична деклинацији сиринићког говора, а да се форме које том систему не припадају јављају спорадично, ексклузивно, у контекстуално условљеним приликама.

Циљ рада јесте, с једне стране, идентификација стандарднојезичких црта у документованом теренском разговору и проналазак њихових дијалекатских еквивалената, а с друге квалитативна анализа исказа у којима се јављају форме стандардног језика како би се увидео њихов однос према вернакулару, потенцијални узроци њиховог јављања, односно улога коју имају у вернакулару.

\section{2. Методологија теренских истраживања и корпус}

Овај рад се заснива на разговору забележеном у Штрпцу 5. 1. 2020. године у трајању од седамдесет минута који је транскрибован у програму Ексмаралда (о програму в. Schmidt, 2009). На снимку је забележена спонтана конверзација између четири особе (у тексту: говорник 1 (1996), 2 (1998), 3 (1995) и 4 (1993)) $)^{7}$. Транскрипт разговора се састоји од укупно 9.825 речи, а за потребе овог истраживања користи се део транскрипта који броји 5.480 речи. Делови су за анализу одабрани на основу тога ко их изговара: користе се само искази говорника 1 и 2 јер се они сматрају релевантним саговор-

\footnotetext{
${ }^{7}$ Говорници 1, 2 и 3 су особе женског пола, а говорник 4 мушког.
} 
ницима за дату тему (о разлозима в. ниже) и они се не пореде међусобно јер нису квантитативно једнаки (говорник 1 изговара 4.329 речи, а 2 свега 1.251 реч). Оба говорника цео живот живе у Штрпцу, с разликом у томе што говорник 2 често путује у Косовску Митровицу, где студира. Говорник 3 је истраживач. Он у разговору учествује једнако као и остали. Користи вернакулар пошто је и са̂м изворни говорник. Говорник 4 изузима се због њему својственог идиолекта. Ради се о особи која је основну и средњу школу завршила у Штрпцу (у којем и тренутно живи), а факултет у Косовској Митровици. Међутим, никада се није користио локалним говором, већ идиолектом који је ближи стандарду, тј. једнак је њему на граматичком нивоу, док одступања постоје пре свега у квалитетским обележјима и месту акцента. Иако особине његовог говора неће бити предмет испитивања, његово присуство би могло имати утицаја на говор осталих.

\section{3. Аналитички приступ}

Истраживање спонтано продукованог говора има предности у виду квалитета материјала, пре свега у томе што саговорници не надгледају своју продукцију говора, већ су усмерени на сам разговор, тј. његов садржај. ${ }^{8}$ Притом, сам разговор није усмераван ни на коју тему од стране истраживача, нити су говорницима постављана питања, па грађа има вредност у потпуности природног говора. Недостатак је у томе што је реч о конверзацији која често садржи кратке исказе, елидиране реченице и сл. У разговору нема дугих наратива, међутим, тај недостатак не утиче толико на актуелну анализу, будући да се испитују форме појединачних речи. У разговору постоје и међусобна прекидања и преклапања која отежавају разумевање.

Из транскрипта су прво издвојени сви падежни облици именица и личних заменица који припадају стандарду. Припадност односно неприпадност неког облика локалном говору одређује се на основу описа сиринићког говора (Младеновић, 2019). Након издвајања стандарднојезичких форми, из остатка материјала ексцерпирају се њихови дијалекатски еквиваленти. Услов да се нека именица сматра дијалекатским еквивалентом за реч исказану у стандарднојезичкој форми јесте да се оне поклапају у категорији рода (и аниматности), броја и падежа. Овако одабрана грађа презентована је у двема табелама од којих прва садржи личне заменице, а друга именице.

\footnotetext{
${ }^{8}$ Према Белићу, кључно за квалитет грађе јесте управо то да говорникова пажња није усмерена на сам језик, већ на садржај који се његовом употребом ствара: „Само дотле док он [саговорник] тако прича, да и не примећује да то чини ради самога језика, темпом обичног говора, његов ће материјал вредети” (Белић, 1905: XXXIV). Такође, материјал добијен из спонтане конверзације као значајан истичу и истраживачи градских говора јер, како Лабов наводи (Labov, 2002: 85), он омогућава и праћење стила и промене стилских регистара говорника у зависности од саговорника и говорне ситуације.
} 
Стандарднојезичке црте и њихови дијалекатски еквиваленти постављени су паралелно, а колоне у којима су наведени разликују се и по боји. Ради лакшег сналажења у тексту и боље прегледности, искази са стандарднојезичким цртама су нумерисани. У тексту је дат квантитативни однос вернакулара и стандарда.

\section{4. Теоријски приступ}

За анализу примењену у овом раду од значаја може бити теорија акомодације у комуникацији (Communication Accommodation Theory) којом се истиче да „по уласку у конверзацију људи одмах (и најчешће несвесно) почињу да прилагођавају аспекте свог вербалног (нпр. акценат, брзину говора) и невербалног понашања (нпр. гестове, држање) једни другима" (Dragojevic i dr., 2014: 36). Кључни појмови овде су конвергенција и дивергенција. За разлику од схватања конвергенције и дивергенције у историјској лингвистици и дијалектологији, где се под њима подразумева „,...] повећање, односно смањење сличности између два дијалеката" (Hinskens i dr., 2005: 1), они су према овој теорији тренутна појава промене у изразу појединаца у одређеном сусрету. Промена се најчешће одвија у оквиру једног језика, не више њих. ${ }^{9}$ Облик и степен акомодације могу варирати у зависности од различитих, најчешће социјалних, фактора (в. Dragojevic i dr., 2014: 36-59) ${ }^{10}$, а за ово истраживање кључни су (а)симетрија у акомодацији и вертикално прилагођавање ${ }^{11}$. Асиметрија подразумева конвергенцију само једне стране према другој, обично се примећује у сусретима особа различитих моћи, али и пола. Вертикално прилагођавање се односи на социјалну вредност, тј. престиж варијетета, при чему се стандарду обично приписује виша вредност $^{12}$. Одређену врсту престижа могу имати и нестандардни варијетети. Према Купланду (Coupland, 2007: 42-43) ${ }^{13}$, они могу имати обрнути прес-

\footnotetext{
${ }^{9}$ Битно је разликовати овакву акомодацију од мењања (и напоредне употребе) језика у конверзацији и иначе у говору билингвала, за шта се користи термин code switching (исп. Auer, 1998) или промена кода.

${ }^{10}$ О овој теорији детаљно у Giles, 2016.

11 Вертикално прилагођавање односи се на перцепцију вредности, односно престижа варијетета у друштву, па се обично сматра да се, уколико се неко прилагођава прелазећи на стандард, ради о прилагођавању 'на више' (Upward/downward adjustment (Dragojevic i dr., 2014: 37)).

${ }^{12}$ Нпр. може се наћи да „стандардне форме указују на средњу класу, образовану или на релативно формалан говор, док је други симбол радничке класе, необразованих или веома колоквијалног говора" (Chambers/Trudgill/Schilling-Estets, 2006: 4).

${ }^{13}$ "They [non-standard varieties] might (in addition) have what has been called 'covert prestige' $[\ldots]$ - prestige that is somehow endorsed below the surface of public discourse, but which leaves
} 
тиж - престиж који постоји ван јавног дискурса и који оставља њихову површну стигматизацију недирнутом, па би однос вернакулара и стандарда у погледу престижа требало посебно испитати, те након тога било којем приписивати одређену позицију у заједници. Битно је, такође, и да акомодација може бити пуна или парцијална у погледу језичких параметара које захвата (може се нпр. променити варијетет или језик у потпуности, али може бити промењен само акценат или темпо (Dragojevic i dr., 2014: 38)) и дуготрајна и краткотрајна у погледу језичких сусрета на које се протеже (говорник с једне стране може конвергирати према саговорнику у свега неколико исказа, а с друге стране може у свакој интеракцији с неким мењати свој израз (Dragojevic i dr., 2041:39)).

\section{5. Сиринићки говор - неке језичке/дијалекатске карактеристике}

Говор северношарпланинске жупе Сиринић један је од говора призренско-јужноморавског типа који Р. Младеновић издваја у засебан део призренско-јужноморавског дијалекта: косовско-метохијско-сиринићки поддијалекат (Младеновић, 2015: 405). Детаљан дијалектолошки опис овог говора дат је у монографији посвећеној овом говору (Младеновић, 2019), а на овом месту су издвојене само неке језичке/дијалекатске карактеристике, које овај говор чине упадљивим у односу на стандардни српски језик. У овом говору стабилисан је пенултимски експираторни акценат у именској и глаголској флексији, док се код прилошких речи са затвореном ултимом може наћи на ултими. Његов вокализам састоји се од основних пет вокала, а садржи и полугласник и вокално $p$, док вокално л зависи од сугласника испред, па иза дентала може имати рефлекс лу, што је, међутим, недоследно и ретко. Између осталог, консонантизам у којем се формирају симетричне корелације опструената по звучности д:т, д’:т’ (ђ:ћ), џ:ч, s:ц, з:с, ж:ш, б:п, г:к, (в:ф) (фрикатив $x$ је испао из система) говор Сиринића сврстава у варијетете који припадају Балканском језичком савезу. У погледу номиналне морфологије, говор Сиринића има четири деклинациона типа (именице м.р. на Ø, -о, -е, -и; с.р.; ж. и м. р. на -а; именица мати), код којих ,у јд. има више падежних дистинкција него у мн., најбоље је очувана флексија у јд. именица - $а$ деклинационог обрасца, аналитизам је највише узнапредовао у с.p." (Младеновић, 2019: 843). Балканистички процеси се огледају и у компарацији: „Поред придева и прилога, у сиринићком говору аналитички се компарирају и именице, заменице, глаголи, предлози (предлошко-падежне конструкције)" (Младеновић, 2019: 564). Младеновић према односу основа бележи осам глаголских врста, а када је реч о глаголским облицима, у Сиринићу је инфинитив смењен конструкцијом да+презент. За грађење футура првог упо-

their 'overt' stigmatisation untouched". 
требљава са граматикализовано ће за свако лице са одговарајућим лицем презента. Од осталих српских говора сиринићки се у презенту разликује само по 3.л.мн. у којем се најчешће уопштава наставак -у, мада не сасвим доследно (Младеновић, 2019: 633-635). У овом су говору јасно аспектуално издиференцирани аорист и имперфекат. Имперфекат је ређе у употреби у односу на аорист, али се фреквентније употребљава у односу на призренско-јужноморавске говоре Косовске и Метохијске котлине. Плусквамперфекат је врло редак, а у систему претериталних облика централно место има перфекат код којег у једнини опстаје моција рода, док је у множини неутралисана наставком -ле. Императив има облике за друго лице оба броја, а могућ је и за 1.л.мн. са конструкцијама ваља да / треба да + презент. Помоћни глагол бити у потенцијалу сведен је на један облик - би.

\section{6. Однос стандардног језика и вернакулара}

\section{1. Деклинација личних заменица ${ }^{14}$}

У анализираној грађи уочени су стандарнојезички облици личних заменица у дативу (1. и 2.л. оба броја) нпр. Мени [изгледа] нормално што знәм; Она нам је морална подршка; Мислим њему не теби; Не могу да вам кажем де; у инструменталу (3.л.јд.) нпр. Нисам ништа имала с ғыим и генитиву (3.л.мн) нпр. Ево ux. Пуни облици личних заменица за 1. и 2. лице оба броја у Сиринићу имају различите форме за номинатив и акузатив (који у овом говору служи и као општи падеж) и оне се формално подударају са стандардом, док разлике постоје у енклитичким облицима. У Сиринићу су облици заменица у дативу следећи: „Датив 1л. јд. и 2. јд. Пуна форма ме́не, те́бе [...] Енклитике ми ти (Младеновић, 2019: 425), „Енклитике [за 1. и 2. л.мн] ни, ви; не, ве" (Младеновић, 2019: 428). Код заменица 3.л.јд. м. и с. р. инструментал се изражава предлошко-падежном конструкцијом с(әс)+ОП (=A) (в. Младеновић 2019: 430), а генитив 3.л.мн. у енклитичком облику гласи ги (в. Младеновић, 2019: 436). У теренском разговору однос стандарда и вернакулара код личних заменица јесте 9:20 (Д 1.л.јд. 2:10; Д 2.л.јд. 1:0; И 3.л.јд 1:2; Д 1.л.мн. 1:3; Д. 2.л.мн. 3:4; Г 3.л.мн. 1:1).

\footnotetext{
${ }^{14}$ В. табелу 1 .
} 


\begin{tabular}{|c|c|c|c|c|c|c|}
\hline Лице & \multicolumn{4}{|l|}{ Једнина } & \multicolumn{2}{|l|}{ Множина } \\
\hline 1. & $\begin{array}{l}\text { 1. [Убеђује } \\
\text { саговорницу да } \\
\text { на Бадње вече } \\
\text { оде код ње] Ће } \\
\text { попиемо винце, } \\
\text { мартини немам, } \\
\text { опрости, али } \\
\text { ће терамо, ће... } \\
\text { Ако је то услов } \\
\text { да дођеш к мени } \\
\text { сутра; } \\
\text { 2. [Одговара на } \\
\text { саговорничину } \\
\text { оцену изгледа } \\
\text { особе која } \\
\text { није присутна] } \\
\text { Мени [изгледа] } \\
\text { нормално што } \\
\text { знәм; }\end{array}$ & \multicolumn{3}{|c|}{$\begin{array}{l}\text { [Одговара на коментар } \\
\text { “Лепо сте окитили јелку”] } \\
\text { Мене ми дава да китим } \\
\text { само од иза; } \\
\text { [Коментарише свој лапсус] } \\
\text { Што ми мене црне беше; } \\
\text { [Укључује се у разговор о } \\
\text { нивоу шећера у крви] Мене } \\
\text { ми је испод [границе]; } \\
\text { Мене два три сата да спавам } \\
\text { више доста; } \\
\text { [У шали оцењује узрок } \\
\text { своје несанице] Она ми } \\
\text { краде мене спавање, } \\
\text { Мене много ми је ружан; } \\
\text { Мене ич не ми се свиђа; } \\
\text { Мене ми је грозан; } \\
\text { Мене два сата ми треба } \\
\text { [за буђење и устајање из } \\
\text { кревета]; } \\
\text { [Заборавила је да госте } \\
\text { понуди соком] О леле } \\
\text { тешко мене; }\end{array}$} & $\begin{array}{l}\text { 5. [Саговорници } \\
\text { у шаљивом тону } \\
\text { разговарају о } \\
\text { томе зашто ће } \\
\text { саговорница } 1 \\
\text { ићи са осталима } \\
\text { на скијалиште } \\
\text { кад не скија } \\
\text { и она даје } \\
\text { закључак о } \\
\text { својој 'сврси’ } \\
\text { тамо] Она нам } \\
\text { је морална } \\
\text { подршка; }\end{array}$ & $\begin{array}{l}\text { [Одговор на коментар } \\
\text { саговорнице да ће им } \\
\text { нешто позајмити] Ће } н и \\
\text { га даш?; } \\
\text { [Говорник } 2 \text { говорнику } \\
4 \text { каже “Једи торту” } \\
\text { мислећи на то да ће скоро } \\
\text { поноћ и да треба избећи } \\
\text { да једе мрсно на Бадње } \\
\text { вече. Будући да је она } \\
\text { и домаћица, та реплика } \\
\text { се могла протумачити и } \\
\text { као коментар да би гости } \\
\text { требало скоро да пођу } \\
\text { кућама] Сам оћала да } \\
\text { кажем не ни је срам што } \\
\text { је касно ал сам сконтала } \\
\text { да му рекла после због } \\
\text { пос; } \\
\text { [Разговара се о одласцима } \\
\text { на скијалиште на Шар- } \\
\text { планини] Али нај ни било } \\
\text { лепо прошли пут; }\end{array}$ \\
\hline 2. & $\begin{array}{l}\text { 3. [При изласку } \\
\text { из собе са } \\
\text { кревета обара } \\
\text { ранац] Паде Дуки } \\
\text { Дасо, извини. } \\
\text { Мислим њему не } \\
\text { теби; }\end{array}$ & \multicolumn{4}{|c|}{\begin{tabular}{|l|l|} 
& \\
6. [Препричава филм] Ово вам је прича \\
само за Вулверин, оно кад био у рат па \\
кад спасио оног што изгоео цео; \\
7. Не могу да вам кажем де, ако гледате \\
филм ће видите да је то у ствари да \\
гледаш то буквално ће се зажалиш што \\
ниси гледала од почетка; \\
8. Сутра ће макнем точкиће, кунем вам \\
се;
\end{tabular}} & $\begin{array}{l}\text { [Одговара на поновљено } \\
\text { питање саговорница да } \\
\text { ли је гладна] Не бре људи } \\
\text { што ви је добро ми е; } \\
\text { [Случајно нагло помера } \\
\text { сто] Точкове сте макле } \\
\text { сутра од сто. Чисто да ви } \\
\text { кажем; } \\
\text { [Препричава свој } \\
\text { разговор са особом која } \\
\text { није присутна] Викам } \\
\text { “идем да ви купим } \\
\text { нешто”; } \\
\text { [Одговара на лоше } \\
\text { коментаре саговорника } \\
\text { на филм] Али што ви је } \\
\text { само искулирајте да је } \\
\text { повезано са прву Зоне и } \\
\text { нормалан филм је то; }\end{array}$ \\
\hline 3. & $\begin{array}{l}\text { 4. [Оцењује } \\
\text { своју везу с } \\
\text { особом која } \\
\text { није присутна] } \\
\text { Не знам } \\
\text { стварно, нисам } \\
\text { ништа имала с } \\
\text { ғим; }\end{array}$ & \multicolumn{2}{|c|}{$\begin{array}{l}\text { Мој тата [кад иде] } \\
\text { на Прчево [брдо] } \\
\text { оволикви нож има } c \\
\text { ґега; } \\
\text { [Планира шта ће } \\
\text { радити док остали } \\
\text { скијају] Ће седим с } \\
\text { юега; }\end{array}$} & \multicolumn{2}{|c|}{$\begin{array}{l}\text { 9. [Показује и } \\
\text { коментарише } \\
\text { видео-снимак] } \\
\text { Ево } и x . \text { Борба са } \\
\text { Волдемором, молићу } \\
\text { лепо, уживо са сета; }\end{array}$} & $\begin{array}{l}\text { Кад ми реко он “Колко } \\
\text { ги имаш” сам сватила } \\
\text { да е више сәм чувена за } \\
\text { мачке; }\end{array}$ \\
\hline
\end{tabular}

Табела 1. 


\section{2. Деклинација именица ${ }^{15}$}

Код именица су забележена одступања од вернакулара у м.р. у трима падежима: генитиву, инструменталу и локативу. Овај деклинациони образац (именице мушког рода на Ø) у говору Сиринића има различите форме за номинатив, датив, акузатив (ОП) и вокатив (Младеновић, 2019: 294-320). За значења генитива и локатива у Сиринићу не постоје посебне форме, већ се најчешће користе предлошко-падежне конструкције са општим падежом: „[...] у предлошко-падежним конструкцијама генитивног значења овог деклинационог обрасца аналитизам је практично истиснуо флексију [...]” (Младеновић, 2019: 301), а „Лјд. опире се аналитизму у конструкцији с предлогом по +, док је уз остале предлоге у овом деклинационом обрасцу практично преовладала аналитичка конструкција" (Младеновић, 2019: 319). Стандардне форме генитива и локатива пронађене у грађи јављају се највише у устаљеним изразима који су у исказ уграђени окамењени: из дна душе ${ }^{16}$, из чиста мира, без обзира, ииљ у животу. Синтагма мањак шећеpa y крви има граматичку структуру преузету у целини из медицинске терминологије. У њој партитивни генитив ${ }^{17}$ прати и локатив именице женског рода (именица крв у Сиринићу спада у именице мушког рода) ${ }^{18}$, што додатно указује на уношење стандардних падежних форми у оквиру честе уобичајене конструкције, не на појединачну замену. За потребе овог рада, све наведене конструкције убрајамо у идиоме, који као појам означавају „више врста вишелексемних спојева, односно синтаксички повезаних лексема с конотативним значењима. У том смислу, он [идиом] је хипероним којим се обухватају и: изреке и терминолошке синтагме, афоризми, пословице, колокације [...] и др.” (Вуловић, 2017: 249). ${ }^{19}$ Последње уочено одступање је у инструменталу који је иначе у Сиринићу аналитичке форме и изражава се предлошко-падежном конструкцијом с(әс) + ОП (Младеновић, 2019: 309).

\footnotetext{
${ }^{15}$ В. табелу 2.

${ }^{16}$ Генитив јд. именице душа није необичан за деклинациони образац именица женског рода на -а у Сиринићу: „Беспредлошки Гјд. јавља се по правилу у предлошко-падежним конструкцијама” (Младеновић, 2019: 365).
}

17 „У партитивној синтагми у служби субјекта, партитивна реч налази се у Гјд., партитивна допуна у Нмн” (Младеновић, 2019: 417). Будући да именица шећер нема множину, било би очекивано да и она буде у једнини, односно на вернакулару би ова синтагма гласима мағак шејћер у крw.

18 „Именице на сугласник некадашњих меких основа ж. р. пришле су именицама м. p.: никакви помоћ немам, па да му тече крш” (Младеновић, 2019: 297).

${ }^{19}$ У овој групи, могла би бити проблематична предлошко-падежна конструкција без обзира, будући да предлог нема лексемно, већ граматичко значење. Међутим, без амбиције да се посебно бавимо терминологијом у овој области, решење за наше груписање грађе остављамо у њеном убрајању у идиоме на основу тога што је употребљена у значењу сличном речци, или чак као поштапалица са значењем небитно. 
Однос стандарда и вернакулара у теренском разговору јесте 7:13 (Г 5:7, И $1: 1$, Л 2:5). Разлог за наведени однос код инструментала (у исказу 9, односно $9^{*}$ ) је тај што је у обзир узето само значење друштва, односно именица са значењем живог, како би парирало маркираном инструменталу из претходног исказа. Уколико би се рачунала и остала значења, која су у овом говору заправо изједначена, ${ }^{20}$ однос би био 4:1 у корист вернакулара.

\begin{tabular}{|c|c|c|c|}
\hline$\Gamma$ & \multicolumn{2}{|c|}{$\begin{array}{l}\text { 10. Ја имам књигу за будућност, Мач од } \\
\text { Шанаре, много добра. После рата раса... } \\
\text { [Прекида је саговорница са „Читала сам”]; } \\
\text { 11. [Одговара на „А што не може да } \\
\text { функционише овде?”] Па на пример можда } \\
\text { оће музику да слуша из чиста мира; } \\
\text { 12. [Одговара на коментар саговорника } 4 \\
\text { да воли прскалице позивајући се на његову } \\
\text { причу да дуже време чека потврду да је } \\
\text { положио државни испит за лекара] Дете. И он } \\
\text { оће после папир од министарство ћути бре ти } \\
\text { [...] без обзира [као] из вртић да си изашо; } \\
\text { 13. [Разговара се о саговорниковом прамену } \\
\text { седе косе] То му је печат. Аа од зрачења } \\
\text { оседео; } \\
\text { 14. [Одговара на коментар „Волим телевизор } \\
\text { кәд је укључен”] Ја га мрзим из дна душе; }\end{array}$} & $\begin{array}{l}\text { [Прича о некима који долазе у црквено } \\
\text { двориште после сече бадњака] Мртви пијани } \\
\text { од бадюак; } \\
\text { Ће ме крене бићи од Божсћ; } \\
\text { [О плану за одлазак на скијалиште] Мислела } \\
\text { сам после Божић; } \\
\text { [Препричава своје дописивање] Кажем “Па } \\
\text { дођи” и тој сәм гу питала да л' ради мислећи } \\
\text { од посо тамән да дође у цркву; } \\
\text { [Одговара на коментар саговорника } 4 \text { да воли } \\
\text { прскалице позивајући се на његову причу } \\
\text { да дуже време чека потврду да је положио } \\
\text { државни испит за лекара] Дете. И он оће } \\
\text { после папир од министарство ћути бре ти } \\
\text { [...] без обзира [као] из вртић да си изашо; } \\
\text { [Светлост ватромета изгледа] као од Хари } \\
\text { Потер; } \\
\text { Точкове [да] сте макле сутра од сто; }\end{array}$ \\
\hline И & \multicolumn{2}{|c|}{$\begin{array}{l}9^{*} . \text { [Показује и коментарише видео-снимак] } \\
\text { Ево их. Борба са Волдемором, молићу лепо, } \\
\text { уживо са сета; }\end{array}$} & Можда треба са Вучића да прича. \\
\hline Л & $\begin{array}{l}\text { 15. Ће га припитомим, само } \\
\text { на мене не ће ржми. То ми је } \\
\text { циљ у животу; } \\
\text { 16. [У шаљивом тону прича } \\
\text { о томе како је чула да } \\
\text { алкохоличари имају мање } \\
\text { шећера у крви] Мањак } \\
\text { шећера у крви тера на } \\
\text { алкохол; }\end{array}$ & \multicolumn{2}{|c|}{$\begin{array}{l}\text { [Обраћа се мачки] Ма́рија а шта носиш у стомак?; } \\
\text { [Укључује се у расправу о средњевековном језику } \\
\text { представљеном у серији „Немањићи”] У средюи век не } \\
\text { причали уопште; } \\
\text { [Реплика на „Ја сам имао страшниу”] Ја сам имала } \\
\text { најстрашниу [гнојну ангину] три месеца не дај боже три } \\
\text { недеље сәм легала у кревет; } \\
\text { [Прича о филму] Ово вам је прича само за Вулверин, оно кад } \\
\text { био у рат па кад спасио оног што изгорео цео; } \\
\text { [Прича о лошем квалитету звука на видео-снимку] Само он се } \\
\text { чуе на крај метните у по далеко како више ће каже не знам; }\end{array}$} \\
\hline
\end{tabular}

табела 2.

\footnotetext{
${ }^{20}$ „Инструментал са значењем оруђа и заједнице у свим деклинационим обрасцима доживео је потпуну аналитизацију” (Младеновић, 2019: 380).
} 


\section{7. Дискусија}

За квалитативни однос стандарда и вернакулара у овом материјалу значајни су постулати из угла теорије акомодације у комуникацији (в. т. 4). На првом месту се истиче једна од поменутих социјалних варијабли, а то је пол. Према овој теорији се „жене чешће прилагођавају мушкарцима него они њима" (Dragojevic i dr., 2014: 38), што би и овде могао бити случај ако узмемо у обзир стандарднојезичке црте код говорника 1 и 2 (женског пола), док говорник 4 (мушког пола) ни у једном тренутку не одступа од свог уобичајеног говора. У истраживаној грађи (сем исказа 12) ${ }^{21}$ нема примера директног обраћања говорнику 4 , но таквих примера има у остатку материјала, нпр. $J a$ сам имала на́јстрашниу [прехладу], где се говорник 1 користи синтетичком компарацијом (у Сиринићу се користи аналитичка, в. т. 5) заједно са променом места акцента (акценат је у овом говору на пенултими, в. т. 5). У сваком случају употребе стандарднојезичких црта, не само у вези са говорником 4 , ради се о промени једне или неколико речи, тј. акомодација је парцијална и краткотрајна, изузев у исказу 9 - Ево их. Борба са Волдемором, молићу лепо, ужсио са сета, у којем заправо изостаје вернакулар. То потврђује да неутралну језичку основу говорника 1 и 2 чини вернакулар, а да се појава стандарднојезичких црта у вернакулару може посматрати као варијација на синтагматском плану, у појединачним исказима, у односу на исказе на вернакулару. ${ }^{22}$ Према (Finegan/Biber, 2002: 235) испитивање варијације изискује анализу унутрашњих (лингвистичких) и спољашних (социјалних и ситуационих) варијабли које са њом корелирају. Унутрашње варијабле подразумевају лингвистичко окружење варијанте; социјалне се тичу пола, етницитета, социјалног статуса итд, док ситуационе подразумевају реципијента, тему, пажљив говор, познатост контекста и формалност, која се најчешће везује за стил (Finegan/Biber, 2002: 235). Узимајући у обзир врло близак и једнак однос саговорника (сви су чланови шире породице), социјалне варијабле се могу изузети (са изузетком пола, који је већ размотрен). То значи да је потребно испитати лингвистичко и ситуационо окружење.

Када је о лингвистичком окружењу реч, не уочава се разлика између паралелно постављених исказа, речи исказане стандарднојезичким формама, као и њихови дијалекатски еквивалетни врше исте службе у реченици, могу се повезивати са истим осталим члановима реченице и место у речени-

\footnotetext{
${ }^{21}$ Такође, помињање радијације (исказ 13 , табела 2) односи се на говорника 4 , а и прецизна формулација медицинске терминологије (16, табела 2$)$ у вези је са његовим присуством, будући да је он доктор медицине.

${ }^{22}$ Поједини истраживачи варијацију виде као претходницу језичкој промени: „Initially [...] dialect contact often leads to abundant variation as a result of dialect mixing, the partial merging of the lexicons and grammars of different but related dialects" (Hinskens, 2005: 9), односно мешању граматика, међутим, у овој грађи нема мешања, већ различите форме коегзистирају због тога што је једна од њих маркирана.
} 
ци ниједне од њих ничим није условљено. Оно што се код једног броја исказа који садрже стандарднојезичке црте може приметити јесте нешто другачија интонација којом се посебно стилизује исказ. ${ }^{23}$ Они то у овим исказима постижу променом боје гласа (тембра) ${ }^{24}$, указујући тиме на додатно значење исказа: на иронију Паде Дуки Дасо, извини. Мислим њему не теби (исказ 3, табела 1); Она нам је морална подрика (5, табела 1); То му је печат. Аа од зрачења оседео (13, табела 2); Ће га припитомим, само на мене не ће ржми. То ми је цииь у животу (15, табела 2) или шалу Ће попиемо винце, мартини немам, опрости, али ће терамо, ће... Ако је то услов да дођеш кмени сутра (1, табела 1); Сутра ће макнем точкиће, кунем вам се (8, табела 1); Мағак шећера у крви тера на алкохол (16, табела 2). У исказу 1 употребљена је предлошко-падежна конструкција к + датив, која осим стандарднојезичке форме датива садржи и предлог који не улази у инвентар овог говора. ${ }^{25}$ На основу тога закључује се да говорник одабир морфолошких (морфосинтаксичких) нетипичних средстава за овај говор користи комплементарно са супрасегментним обележјима ради стилизације исказа и помоћу њих указује на додатни смисао исказа. На супрасегментном нивоу приметно је, такође, да се у исказима 2 (табела 1) Мени [изгледа] нормално што зндм и 4 (табела 1) Не знам стварно, нисам ништа имала с њим; врло изразит логички акценат налази управо на стандарднојезичкој форми. Овако постављен логички акценат проналази се и у већ поменутим исказима 1 и 3 (в. горе), као и у 11, 12, 14, 15 и 16, о којима ће бити речи касније. За разлику од њих, ова два исказа (1 и 4) немају никаква додатна обележја. Ипак, на основу логичког акцента се стандарднојезичка црта јасно издваја од остатка речи од којих је такође одвојена и паузом, што указује на то да су говорници свесни да се служе формом која не припада њиховом говору.

Када је реч о ситуационим варијаблама, може се издвојити тема ${ }^{26}$ која се у појединим деловима конверзације може јасно дефинисати. У том случају прво се као тема може издвојити филм Ово вам је прича само за Вул-

23 Изучавајући стил и промену стила у тренутном изразу, као индикаторе промене лингвистичког понашања и емотивне укључености, тј. преласка из једног у други говор или нијансе у њима, Лабов наводи промену у интензитету тона, у тону, темпу, дисању, смеху (Labov, 2002: 89).

${ }^{24}$ Тембрална компонента односи се на боју гласа, на јединственост гласа и реченичног тона код сваке особе и њена промена нужно сигнификује и промену израза, тј. у њега интегрише додатне информације „њене основне функције везују [се], готово без изузетака, за емоционални аспект исказа" (Јокановић-Михајлов, 2013: 219-220). Користи се у сценском говору и сродним дисциплинама најчешће као средство за имитацију и сл, док је у свакодневном говору ређа и обично указује на иронију, тепање, шаљив тон и слично.

${ }^{25}$ „Није забележен предлог к(а)” (Младеновић, 2019: 768).

${ }^{26}$ Тему разговора као значајну за одабир израза код говорника из Ниша примећује и П. Л. Тома: „пропорција стандардних и дијалекатских облика зависи од теме разговора” (Тома, 1998: 434). 
верин, оно кад био у рат па кад спасио оног што изгорео цеео (6, табела 1), Не могу да вам кажем де, ако гледате филм ће видите да је то у ствари да гледаш то буквално ће се зажалиш што ниси гледала од почетка (7, табела 1), Ево их. Борба са Волдемором, молићу лепо, уживо са сета (9, табела 1), уз њега и књига сличног жанра Ја имам књигу за будућност, Мач од Шанаре, много добра. После рата раса... (10, табела 2), што се посебно види у исказу 9 (односно $9^{*}$ у табели 2 ), који је у целини на стандардном језику, за разлику од свих других исказа на вернакулару. Говорница 1 овај исказ изговара враћајући се у разговор након потраге за видео-снимком на свом телефону, не прилагођава се било коме од саговорника, већ налази 'доказ' за претходну тему (како је учествовала у ватромету за Нову годину), о којој је говорила на вернакулару. Исказ се односи на нетипичну ситуацију и она има потребу да је опише на шаљив начин, користећи се модерним реалијама: референцом на филм и терминологијом из области филма.

Како је у одељку 6. 2. наведено, у грађи постоји и одређен број идиома који су унели синтетичку деклинацију у вернакулар (искази $11,12,14,15$, 16). Осим у исказима 15 и 16 (в. табелу 2), ови елементи нису инонационо маркирани, што указује на њихову потпуну адаптираност у исказу, не чине се као граматички или функционално страни делови реченице. На овакав статус утиче њихов идиоматски карактер: они су семантички маркирани као целина, па се њихове појединачне граматичке особине занемарују.

\section{8. Закључна разматрања}

Целокупна грађа у погледу деклинације јесте одраз датог вернакула$\mathrm{pa}$, а тек поједини искази садрже стандарднојезичку црту. Премда се ради о грађи малог обима и селектованим језичким формама које се паралелно посматрају у вернакулау и деловима исказа на стандардом језику, квантитативни однос примера на вернакулару и стандарду говори у корист првог, односно указује да је вернакулар постојана језичка структура. Употреба стандарднојезичких форми указује на висок степен компетенције говорника за стандардни језик - свака стандарднојезичка форма употребљена је у значењу и функцији коју би имала и у исказу на стандардном језику. Осим морфосинтаксичких стандарднојезичких црта, промену облика прати и промена на плану прозодије - у највећем броју примера промењено је и место акцента. Учесници у разговору праве разлику између вернакулара и стандарда и на основу тог знања се повремено у говору на вернакулару користе елементима из стандардног језика како би унели додатна значења у реченични смисао. Појединачне речи (или синтагме) имају контекстуално и/или тематски условљену функцију у исказу у којем се употребљавају, али не утичу на његову морфолошку структуру. Контекстуално условљене 
стандарднојезичке црте јављају се у исказима чија интонација указује на интенцију говорника да њиме пренесе додатну поруку, да укаже на иронију, шалу и сл. У тим случајевима стандарднојезичка црта, на којој је и логички акценат, функционише као још један показатељ да се не ради о неутралном исказу. Тема разговора која елицитира већи број стандарднојезичких црта јесте филм, односно књига. О каквој је корелацији реч, требало би посебно изучити, могло би имати везе са одвајањем реалија које се тичу образовања и модерног живота и њиховог везивања за стандардни језик од свакодневних, мање специфичних тема за које се користи вернакулар. Трећу групу исказа у којима се јављају стандарднојезичке црте чине они који нису ни на који начин маркирани. Они садрже изразе идиоматског карактера који су у потпуности уклопљени у исказ и разговор, а њихово присуство се може објаснити преузимањем из стандардног језика без морфолошке адаптације у вернакулару.

Спроведена анализа и одабран смер истраживања дали су резултате у истраживању употребе морфосинтаксичких облика стандардног језика у вернакулару. За овај прилог одабрана је деклинација именица и личних заменица, а на материјалу који је овде коришћен могу се спровести даља испитивања других врста речи и њихових категорија, попут глагола и глаголских облика, компарације придева и прилога итд. Такви би радови допринели комплетнијем сагледавању односа употребе стандарднојезичких и вернакуларних морфосинтаксичких облика.

\section{Литература}

Белић, 1905: А. Белић, Дијалекти источне и јужне Србије. Београд : Државна штампарија краљевине Србије.

Бошњаковић и др., 2009: Говор Новог Сада. Св. 1, Фонетске особине. Нови Сад: Филозофски факултет у Но-

вом Саду, Одсек за српски језик и лингвистику.

Бугарски, 2009: Р. Бугарски, Теоријске основе урбане дијалектологије. Говор Новог Сада. Св. 1, Фонетске особине. Нови Сад: Филозофски факултет у Новом Саду, Одсек за српски језик и лингвистику.13-31.

Вуловић, 2017: Н. Вуловић, Употреба основних фразеолошких термина у српској (и словенској) лингвистици. $\quad$ у: Словенска терминологија данас. Београд: Српска академија наука и уметности, Институт за српски САНУ, 243-252.

Јокановић-Михајлов, 2013: Ј. Јокановић-Михајлов, Акценат и интонащија говора на радију и телевизији. Београд: Друштво за српски језик и књижевност (друго издање). 
Милорадовић, 2016: С. Милорадовић, Говорни тип града - комуникацијска стратегија и идентификацијска пракса у Србији данас. У: Релација град-село на словенска територија денес: (лингвистичко-соииолошка анализа), Скопје: Македонска академија на науките и уметностите, 77-92.

Младеновић, 2015: Р. Младеновић, Акценат и гласови подримског говора. Cpnски језик, XX, 441-457.

Младеновић, 2019: Р. Младеновић, Говор шарпланинске жупе Сиринић. Српски дијалектолошки зборник, LXVI/1, 1-1050.

Тома, 1998: П. Л. Тома, Говори Ниша и околних села. Београд: Српска академија наука и уметности и Институт за српски језик САНУ.

Трајковић, Татјана (2015) Говор Прешева. <https://nardus.mpn.gov.rs/bitstream/ handle/123456789/5537/Disertacija3464.pdf? sequence $=6 \&$ isAllowed $=y$ $>$.Датум преузимања: 10.11.2020.

Трајковић, 2018: Т. Трајковић, Говор Ниша кроз призму диглосивности. Јужнословенски филолог, LXXIV/2, 89-108.

Auer, 1998: P. Auer, Code-Switching in Conversation: Language, Interaction and Identity. London: New Fetter Lane.

Chambers, Trudgill, Schilling-Estets, 2006: J. K. Chambers, P. Trudgill, N. SchillingEstets. The Handbook of Language Variation and Change. Oxford: Blackwell Publishing Ltd.

Coupland, 2007: N. Coupland, Style (Language Variation and Identity). Cambridge: Cambridge University Press.

Dragojevic, Gasiorek, Giles, 2014:M. Dragojevic, J. Gasiorek, H. Giles, Accommodative Strategies as Core of the Theory, in: Communication Accommodation Theory: Negotiating Personal Relationships and Social Identities across Contexts. Cambridge: Cambridge University Press, 36-59.

Finegan, Biber, 2003: E. C. R. Finegan, D. Biber, Register variation and social dialect variation: the Register Axiom, in Dialect Change Convergence and Divergence in European Languages, 11. Cambridge: Cambridge University Press, 235-267.

Hinskens, Auer, Kerswill, 2005: F. Hinskens, R. Auer, P. Kerswill, The study of dialect convergence and divergence: conceptual and methodological considerations, in: Dialect Change (Convergence and Divergence in European Languages), 10, 1. Cambridge: Cambridge University Press, 1-48.

Giles, 2016: H. Giles, Communication accommodation theory: negotiating personal relationships and social identities across contexts. United Kingdom: Cambridge University Press.

Labov, 1966: W. Labov, The Social Stratification of English in New York City. Washington: Center for Applied Linguistics.

Labov, 2002: W. Labov, The anatomy of style-shifting, in: Style and Sociolinguistic Variation, 8. Cambridge: Cambridge University Press, 85-108.

Labov, 2006: W. Labov, The Social Stratification of English in New York City. Cambridge University Press (second edition). 
Schmidt, 2009: T. Schmidt, Creating and Working with Spoken Language Corpora in EXMARaLDA, in:LULCL II: Lesser Used Languages \& Computer Linguistics II, 151-164.

Trajković, 2017: T. Trajković, Niš speech in the light of the newest sociolinguistic research. Teme, XLI /1, 41-54.

\title{
ELEMENTS OF STANDARD SERBIAN LANGUAGE IN A LOCAL VARIETY OF SIRINIĆ
}

\begin{abstract}
Summary
This paper is based on an analysis of a transcribed conversation between four people who are speakers of Sirinić speech variety, which belongs to Prizren-Timok dialect area. Although the interlocutors use this local variety in daily communication, they adopted the standardized forms of Serbian language throughout their education. They are also exposed to it on a daily basis through media they consume. Therefore, even though based on a vernacular, their expressions also contain standard language forms. In this paper we examine the usage and the representation of standard language forms of nouns and personal pronouns with the goal to determine the reason of their appearance in this vernacular: we want to answer whether they are deviations caused by a specific context or whether they are potential changes in this speech system. In the transcribed data, grammatical forms which belong to standard Serbian language are identified and their dialectal equivalents are found. The quantification of variants confirmed that vernacular is more represented, and applying qualitative analysis to the usage of standard language forms confirmed that they appear in vernacular forms only in specific situations. Speakers use standard elements in three cases: as a part of stylized statements and in those statements related to a particular topic; within idiomatic expressions, which are perceived as a unit with its unique meaning: this leads to speakers being less likely to notice they are using forms atypical for their usual speech; and within a combination with a logical accent in the sentence, used as a means of emphasizing a particular part of the sentence.
\end{abstract}

Key words: peripheral variety, vernacular, standard language, declination, declension, noun, personal pronouns, variation 